\title{
Emosi dan Penggunaan Warna Dominan Pada Kegiatan Mewarnai Anak Usia Dini
}

\author{
Putu Yudari Pratiwi dan I.G.A.P. Wulan Budisetyani \\ Program Studi Psikologi, Fakultas Kedokteran, Universitas Udayana \\ pyudariry@gmail.com
}

\begin{abstract}
Abstrak
Penelitian ini bertujuan mengetahui pengaruh emosi terhadap penggunaan warna dominan pada kegiatan mewarnai anak usia dini serta melihat pengaruh emosi positif dan negatif terhadap warna dominan yang digunakan. Emosi adalah kondisi yang melibatkan aspek fisiologis, psikologis, dan perasaan untuk bertindak karena adanya stimulus yang diterima indera dan nantinya akan direspon serta diproses. Emosi anak pada umumnya terdiri dari marah, takut, gembira, sedih, cemburu, kasih sayang, ingin tahu, dan iri hati yang diungkapkan dengan ekspresi yang sama. Emosi dapat dibagi menjadi emosi positif yaitu bahagia, excitement, dan terkejut serta emosi negatif yaitu marah, sedih, takut, dan jijik. Emosi positif seringkali dihubungkan dengan warna cerah dan emosi negatif dihubungkan dengan warna gelap. Kesimpulan yang didapat warna memanifestasi emosi yang dirasakan oleh individu.

Rancangan penelitian adalah quasi eksperimen dengan desain treatment by subject. Sampel penelitian sebanyak 30 siswa berasal dari TK Tunas Mekar Sari yang dipilih dengan teknik purposive sampling. Alat ukur untuk menentukan warna dominan pada kegiatan mewarnai menggunakan teknik penghitungan luas warna dengan teknik grid atau square method, sehingga didapat warna yang paling luas hingga paling sempit. Metode analisis data yang digunakan adalah teknik analisis fungsi Crosstabs, Chi Square, dan Koefisien Kontingensi.

Analisis data dan hasil penelitian menemukan bahwa ketiga hipotesis yang ada diterima yaitu ada pengaruh antara emosi terhadap penggunaan warna dominan pada kegiatan mewarnai anak usia dini, ada pengaruh antara emosi positif terhadap penggunaan warna dominan cerah, serta ada pengaruh antara emosi negatif terhadap penggunaan warna dominan gelap.
\end{abstract}

Kata kunci : emosi, warna dominan, anak usia dini

\begin{abstract}
This study aims to determine the emotion influence towards use of the dominant color on early childhood coloring activities and also see the influence of positive and negative emotions toward the dominant color that used. Emotions are a condition that involves physiological, psychological, and feelings to act, because of the stimulus received by the senses, will be response, and processed. Emotions can be divided into positive emotions consist of happiness, excitement, also surprise and negative emotions consist of anger, sadness, fear, and disgust. Colors can manifest emotions that felt by someone. Bright color associated with positive emotions, and the dark color associated with negative emotions. Dominant color is color that most widely used in one image area. To count the area of the color is using grid technique or square method.
\end{abstract}

This study use quasi experimental design with treatment by subject. The sampling was 30 students from Tunas Mekar Sari Kindergarten that taken by purposive sampling technique. The data analysis methods are using Crosstabs function, Chi-Square Test, and Coefficient Contingency C.

Data analysis and study result find there are three hypotheses received, those are the strong emotion influence towards use of the dominant color on early childhood coloring activities, the strong positive emotion influence towards use of the bright dominant color, also the very strong negative emotion influence towards use of the dark dominant color.

Keywords: turnover intention, psychological contract violation, type A personality, bank employees 


\section{LATAR BELAKANG}

Menurut Froebel, masa kanak-kanak dipandang sebagai masa emas (golden age) yang merupakan masa otak mengalami pertumbuhan dan perkembangan yang pesat yang terjadi ketika anak berusia 0-6 tahun. Tahap ini merupakan tahap awal kehidupan manusia yang menentukan bagaimana sikap, perilaku, dan kepribadian individu di masa depan (dalam Mashar, 2011). Pada umumnya pada tahap ini anak usia dini belajar mengenai berbagai hal termasuk dalam mengembangkan kemampuan motorik, kognitif, bahasa, serta sosioemosional mereka.

Perkembangan motorik merupakan proses perkembangan yang berlaku pada pengendalian jasmani melalui kegiatan pusat saraf, urat saraf, dan otot-otot yang terkoordinasi. Perkembangan kognitif menurut Piaget berhubungan dengan perkembangan otak anak yaitu mengenai daya pikir dan bagaimana anak mulai mengeksplorasi lingkungan dengan panca inderanya (dalam Susanto, 2011). Piaget juga menyebutkan perkembangan kognitif pada tahap ini adalah tahap pra-operasional yang berlangsung antara usia 2-7 tahun. Anak-anak mulai mewakili dunia dengan kata-kata, citra, dan gambar (dalam Santrock, 2011).

Perkembangan bahasa penting didapat anak ketika berada pada usia dini. Bahasa yang dimiliki membantu anak dalam berkomunikasi baik lisan maupun tertulis serta membantu anak mengungkapkan isi pikirannya (dalam Susanto, 2011).

Perkembangan sosioemosional dapat digolongkan menjadi dua macam, yaitu perilaku atau perkembangan sosial dan perkembangan emosional. Perkembangan sosial menurut Erickson menekankan pada interaksi anak dengan lingkungan baik itu dengan orangtua atau teman sebaya. Perilaku sosial pada anak usia dini diarahkan untuk perkembangan sosial yang baik seperti kerja sama, tolong-menolong, berbagi, simpati, empati, dan saling membutuhkan satu sama lain (Syaodih, 2010). Perkembangan emosional merupakan perkembangan dari relasi yang terorganisasi dan muncul terhadap hal-hal yang berhubungan dengan kebutuhan, tujuan, ketertarikan, dan minat individu.

Perkembangan emosional pada anak juga menekankan pemahaman pada reaksi emosional orang lain dan mulai belajar untuk mengendalikan emosinya sendiri (Santrock, 2011). Menurut Cole, dkk (2009) pada tahap ini anak belajar untuk memahami beberapa hal antara lain keadaan tertentu dapat membangkitkan emosi tertentu, ekspresi wajah mengindikasikan emosi tertentu, emosi memengaruhi perilaku, dan emosi juga dapat memengaruhi emosi orang lain (dalam Santrock, 2011).

Memperhatikan perkembangan-perkembangan di atas belum menjadi jaminan nantinya anak tumbuh secara optimal. Menurut Mashar (2010) ternyata ada sisi lain yang juga tidak kalah penting pada perkembangan anak, yaitu emosi. Peran emosi pada anak merupakan salah satu bentuk komunikasi agar anak dapat menyatakan segala kebutuhan dan perasaannya kepada orang lain serta berperan dalam memengaruhi kepribadian dan penyesuaian diri anak dengan lingkungan sosialnya. Hal ini mendasari pemikiran bahwa memang secara umum emosi merupakan salah satu faktor penting dalam perkembangan anak dengan orang lain dan lingkungannya.

Emosi pada anak-anak juga unik. Hal ini dapat dilihat dari salah satu ciri emosi pada anak yaitu beberapa pola emosi berbeda ditunjukkan dengan perilaku yang sama (Hurlock, 1992). Ciri unik ini menimbulkan kesulitan dalam membedakan apa yang anak-anak rasakan sehingga membuat orangtua terkadang salah merespon apa yang anak rasakan dan berdampak pada kurang optimalnya perhatian orangtua terhadap emosi yang dirasakan oleh anak di Indonesia (Mashar, 2011).

Kurangnya ketepatan respon yang ditunjukkan orangtua secara tidak langsung memberikan dampak negatif yang dapat memengaruhi perkembangan serta kecenderungan pribadi anak di usia dewasa. Menurut Izzaty (2005) ada beberapa dampak negatif yang timbul antara lain agresivitas, kecemasan, temper tantrum, menarik diri, dan ketakutan yang berlebihan (dalam Mashar, 2011). Menurut Mashar (2011) dampak lain yang bisa timbul adalah kurangnya afeksi pada anak yang berlanjut pada sulitnya mengembangkan ikatan emosional, hipersensitivitas, dan kecenderungan bunuh diri.

Erickson menyatakan individu yang berusia 4-5 tahun masuk dalam tahap initiative versus guilt. Tahap ini ditunjukkan dengan kemampuan anak untuk melakukan partisipasi dalam berbagai kegiatan fisik dan mengambil inisiatif untuk suatu tindakan yang dilakukan. Ketidaktahuan orangtua terhadap apa yang dibutuhkan anak pada tahap ini membuat orangtua membatasi kegiatan eksplorasi yang dilakukan. Anak tidak mampu mengungkapkan apa yang mereka inginkan sehingga memunculkan emosi yang kuat dengan berdampak pada kesulitan belajar, kesulitan mengingat, serta menurunnya keterampilan anak (dalam Susanto, 2011). Dampak-dampak negatif ini dapat dihindari dengan menyelaraskan emosi yang dirasakan anak dengan respon yang tepat dari orangtua anak. Penyelarasan dapat dilakukan dengan menemukan sebuah teknik atau metode alternatif yang mampu menjawab kebutuhan tersebut.

Emosi muncul pada individu karena adanya stimulus dari lingkungan yang diterima oleh indera (Atwater, 1983). Hal ini juga terjadi pada anak. Emosi pada anak muncul dengan adanya rangsangan-rangsangan stimulus yang berasal dari dalam diri individu, konflik dalam proses perkembangan, dan lingkungan (Mashar, 2011). Salah satu contoh rangsangan yang bersumber dari lingkungan adalah film yang ditonton anak. Film adalah karya cipta seni dan budaya yang merupakan media komunikasi massa pandang-dengar dan 
dibuat berdasar asas sinematografi. Film mampu memberi rangsangan pada emosi karena salah satu fungsi film dapat mempengaruhi individu dalam bertindak (Nando, 2011).

Film merupakan hal yang menarik bagi anak. Hal ini karena kognitif anak usia dini berada pada subtahap pemikiran intuitif yang membuat mereka lebih mudah mencerna hal yang dilihat, adanya peningkatan perhatian secara visual, serta kecenderungan untuk memperhatikan stimulus yang menonjol dan mencolok (Santrock, 2011) seperti yang disajikan oleh film. Jadi film dengan tema tertentu dapat mempengaruhi individu dalam berperilaku tertentu.

Pada tahap perkembangannya anak memerlukan stimulasi-stimulasi berupa kegiatan positif salah satunya melalui kegiatan mewarnai. Kegiatan mewarnai menjadi pilihan karena memiliki banyak manfaat untuk perkembangan anak (Farida, 2009). Beberapa manfaat yang didapat ketika anak mewarnai antara lain mengungkapkan imajinasi yang dimiliki, membantu mengenal perbedaan warna, melatih motorik halus, meningkatkan konsentrasi, dan melatih anak membuat target. Selain itu menurut penelitian milik Goldstein (1939) penggunaan warna oleh anak-anak pada kelas seni secara tidak sadar merupakan manifestasi dari emosi yang mereka rasakan. Hal ini memberikan suatu pandangan bahwa kegiatan mewarnai cukup memungkinkan untuk melihat emosi yang sedang dirasakan anak.

Hal inilah yang membuat peneliti tertarik untuk melihat hubungan antara emosi dan warna dengan menggunakan media film sebagai rangsangan untuk memunculkan emosi pada anak. Dari paparan di atas memunculkan asumsi peneliti bahwa warna dapat dijadikan salah satu teknik untuk mengungkapkan emosi yang dirasakan anak. Rumusan masalah penelitian pun menjadi apakah ada pengaruh emosi terhadap penggunaan warna dominan pada kegiatan mewarnai anak usia dini untuk mencapai tujuan penelitian yaitu ingin melihat pengaruh emosi terhadap penggunaan warna dominan pada kegiatan mewarnai.

\section{METODE}

\section{Hipotesis}

Penelitian ini menggunakan satu hipotesis mayor dan dua hipotesis minor, antara lain :

\section{Hipotesis Mayor}

Ho : Tidak ada pengaruh emosi terhadap penggunaan warna dominan pada kegiatan mewarnai anak usia dini

Ha : Ada pengaruh emosi terhadap penggunaan warna dominan pada kegiatan mewarnai anak usia dini

\section{Hipotesis Minor}

1) $\mathrm{Ho}_{1}$ : Tidak ada pengaruh emosi positif terhadap penggunaan warna dominan cerah pada kegiatan mewarnai anak usia dini
$\mathrm{Ha}_{1}$ : Ada pengaruh emosi positif terhadap penggunaan warna dominan cerah pada kegiatan mewarnai anak usia dini

2) $\mathrm{Ho}_{2}:$ Tidak ada pengaruh emosi negatif terhadap penggunaan warna dominan gelap pada kegiatan mewarnai anak usia dini

$\mathrm{Ha}_{2}$ : Ada pengaruh emosi negatif terhadap penggunaan warna dominan gelap pada kegiatan mewarnai anak usia dini

\section{Variabel dan definisi operasional}

Penelitian ini menggunakan satu variabel bebas yaitu emosi dan satu variabel tergantung yaitu warna dominan.

\section{Emosi}

Emosi merupakan suatu kondisi secara psikologis dan fisiologis untuk bertindak karena adanya stimulus yang diterima indera. Emosi dibagi menjadi emosi positif yaitu bahagia, excitement, kasih sayang, dan terkejut atau heran (wonder); dan emosi negatif yang terdiri dari marah, sedih, takut, dan jijik.

Emosi yang diharapkan muncul dimanipulasi dengan pemberian stimulus menonton film dengan tema yang sesuai emosi. Film dipilih sebagai perlakuan pada penelitian ini dibandingkan menggunakan perlakuan mendongeng dan gambar seperti penelitian sebelumnya dengan alasan antara lain :

1. Anak usia 4-6 tahun berada pada subtahap pemikiran intuitif sehingga masih kesulitan dalam memahami sesuatu yang tidak dilihat secara langsung (Santrock, 2011). Kesulitan memahami yang tidak dilihat secara langsung membuat mendongeng tidak dipilih karena ketakutan tidak bisa menstimulasi emosi anak ketika diberi perlakuan.

2. Adanya peningkatan perhatian secara visual dan kecenderungan untuk memperhatikan stimulus yang menonjol dan mencolok (Santrock, 2011) sehingga film lebih tepat dibandingkan perlakuan lain.

Tema untuk film-film yang ditampilkan adalah cerita yang memunculkan emosi bahagia, sedih, takut, dan kasih sayang.

\section{Warna Dominan}

Berasal dari adaptasi penelitian milik Boyatzis \& Varghese (1994) yang menggunakan sembilan warna dalam penelitiannya yaitu merah muda, merah, kuning, hijau, ungu, dan biru yang tergolong warna cerah; warna hitam, coklat, dan abu-abu yang tergolong warna gelap. Pada penelitian ini ditambahkan 3 warna yang akan digunakan dalam perlakuan yang diberikan sehingga total warna yang digunakan menjadi 12 warna. Terdiri dari warna yang tergolong cerah yaitu merah muda, oranye, kuning, hijau muda, biru muda, dan ungu; warna yang tergolong gelap yaitu merah tua, hijau tua, biru tua, coklat, abu, serta hitam. Penambahan 3 warna bertujuan agar jumlah warna gelap dan cerah yang digunakan sama 
banyak sehingga jumlah warna yang digunakan menjadi berimbang.

Warna cerah dihubungkan dengan perasaan positif dan warna gelap dihubungkan dengan perasaan negatif. Penggunaan warna dominan dilihat dari seberapa luas warna pada bidang gambar dan akan dibuat kriterianya oleh peneliti serta selanjutnya dilakukan peratingan dari warna yang paling banyak digunakan atau paling luas wilayah warnanya hingga warna yang paling sedikit digunakan. Kriteria dan langkah penghitungan dimodifikasi dari teknik penghitungan luas dengan teknik grid atau square method.

\section{Anak Usia Dini}

Dalam penelitian ini anak usia dini yang digunakan dari rentang usia 4-6 tahun. Dipilihnya rentang usia ini karena beberapa pertimbangan, antara lain :

1) Anak sudah dapat berpartisipasi dalam suatu percakapan, mampu mendengarkan orang lain yang berbicara, dan menanggapi pembicaraan; sehingga akan lebih mudah untuk memberikan instruksi, serta lebih dapat memberikan perhatian pada pemberi instruksi sehingga membantu kelancaran wawancara.

2) Anak dapat berbicara mengenai perasaan mereka dengan cara sederhana yang diharapkan membantu proses wawancara.

3) Salah satu ciri perkembangan sosial anak dalam rentang usia ini mulai dapat mengikuti dan mematuhi aturan sehingga membantu kelancaran penelitian.

4) Anak usia 4-6 tahun ini tetap memberikan ciri emosi anak usia dini, yaitu beberapa pola emosi yang mereka rasakan ditampilkan dalam beberapa pola perilaku yang sama sehingga sulit dibedakan.

\section{Subjek Penelitian}

Subjek penelitian berasal dari populasi siswa-siswi yang berusia 4-6 tahun dari Taman Kanak-Kanak Tunas Mekar Sari, Denpasar yang dipilih menggunakan metode purposive sampling.

Purposive sampling dipilih karena metode ini mampu menyesuaikan kebutuhan peneliti pada subjek yang tepat digunakan dalam penelitian. Cara penentuan sampel dengan purposive sampling ini diawali dengan mengumpulkan seluruh populasi siswa-siswi Taman Kanak-Kanak Tunas Mekar Sari, Denpasar sebanyak 120 orang. Berdasarkan populasi yang ada dipilih siswa-siswi yang memenuhi kriteria yang telah ditetapkan oleh peneliti sebelumnya. Kriteria disusun untuk membantu kelancaran penelitian. Pemilihan sampel sesuai dengan kriteria dilakukan melalui observasi awal yang dilakukan, hasil wawancara, dan rujukan dari guru kelas.

\section{Metode pengumpulan data}

\section{Data Primer}

Data primer adalah dokumentasi berupa hasil mewarnai subjek. Untuk objek yang diwarnai merupakan gambar yang diberikan secara pararel. Gambar pararel terdiri dari dua gambar dengan objek yang serupa tapi tidak sama. Pengukuran data primer yang didapat menggunakan teknik grid atau square method. Teknik grid atau square method ini adalah salah satu cara pengukuran luas suatu bidang datar dengan membuat petak-petak pada gambar dalam bentuk bujur sangkar yang berukuran sama (Gayo, 2013). Teknik ini juga dapat digunakan untuk mengukur luas bidang yang tidak beraturan seperti luas dari daun. Pada bidang pertanian penghitungan luas daun dengan menggambar daun yang ingin diukur luasnya pada kertas lalu dilakukan pengukuran pada gambar yang telah dibuat menggunakan teknik grid atau square method sehingga di dapat luas gambar daun sekaligus luas daun sebenarnya (Napisah, 2013).

Kemampuan teknik ini untuk mengukur luas bidang yang tidak beraturan menjadi alasan menggunakan teknik ini dalam mengukur luas warna yang digunakan pada objek mewarnai. Hal ini karena objek gambar dan objek yang diwarnai merupakan bidang yang tidak beraturan sehingga sulit jika menggunakan pengukuran luas bidang dengan metode sederhana. Teknik grid atau square method dapat dikatakan tepat untuk mengukur luas warna pada objek mewarnai yang merupakan data primer penelitian ini.

Cara penggunaan teknik grid atau square method dengan mengukur luas masing-masing warna yang ada pada hasil mewarnai dalam bidang gambar. Langkah-langkah penghitungan luas warna pada hasil mewarnai antara lain :

1. Pada kertas hasil mewarnai ditarik garis-garis horizontal dan garis-garis vertikal dengan jarak antara satu garis dengan garis berikutnya sebesar $1 \mathrm{~cm}$.

2. Hasil yang didapat setelah menarik seluruh garis horizontal dan vertikal yaitu kertas mewarnai telah dipenuhi kotak-kotak atau bujur sangkar dengan ukuran 1x1 cm.

3. Pengukuran masing-masing warna dihitung berdasar jumlah bujur sangkar yang dikenai warna dengan rincian bujur sangkar penuh dihitung 1 kotak dan yang tidak penuh dihitung mulai dari ukuran 0,$9 ; 0,8 ; 0,7 ; 0,6 ; 0,5 ; 0,4 ; 0,3 ; 0,2 ; 0,1$.

4. Total dari warna yang telah dihitung jumlah kotaknya dikalikan dengan $1 \mathrm{~cm}^{2}$ sehingga didapat luas warna tersebut.

5. Dari seluruh warna yang dihitung dicari warna yang paling luas sebagai warna dominan yang digunakan.

Berikut ini adalah pemaparan contoh langkahlangkah teknik grid atau square method:

1. Gambar berikut adalah contoh data primer hasil mewarnai : 


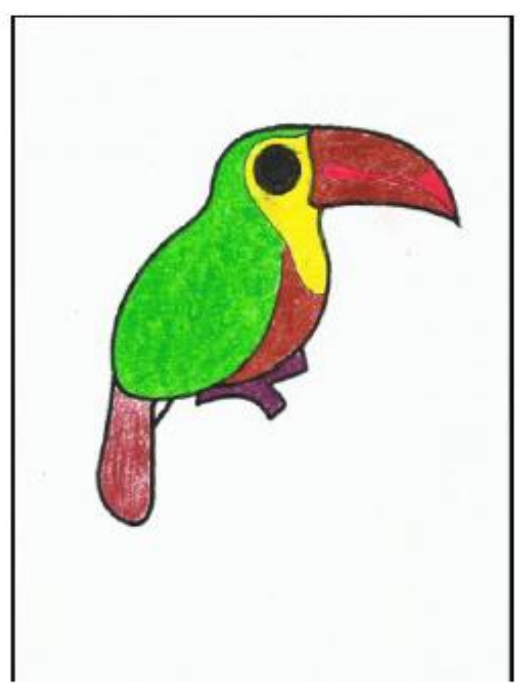

Gambar 1

\section{Contoh Hasil Mewarnai Subjek}

2. Dari data primer yang didapat ini kemudian ditarik garis-garis horizontal dan garis-garis vertikal dengan jarak antara satu garis dengan garis berikutnya sebesar $1 \mathrm{~cm}$ sehingga hasil yang didapat sebagai berikut :



\section{Gambar 2}

\section{Contoh Hasil Mewarnai setelah Diberi Garis Vertikal dan}

\section{Horisontal}

3. Kemudian dilakukan penghitungan dari warna-warna yang ada pada contoh gambar yaitu warna hijau tua, kuning, coklat, merah, serta hitam dan dimasukkan ke dalam tabel guna mempermudah pencatatan hasil.
Bentuk tabel yang digunakan sebagai berikut :

$$
\text { Tabel } 1
$$

Luas Warna yang Digunakan

\begin{tabular}{|c|c|c|c|}
\hline \multirow[t]{2}{*}{ No } & \multirow[t]{2}{*}{ Warna } & \multicolumn{2}{|c|}{ Luas Warna } \\
\hline & & dalam $\left(\mathrm{cm}^{2}\right)$ & dalam (\%) \\
\hline 1 & Kuning & 11,5 kotak $\times 1 \mathrm{~cm}^{2}=11,5 \mathrm{~cm}^{2}$ & $11 \%$ \\
\hline 2 & Ungu & 4,5 kotak $\times 1 \mathrm{~cm}^{2}=4,5 \mathrm{~cm}^{2}$ & $4 \%$ \\
\hline 3 & Merah Muda & 4,5 kotak x $1 \mathrm{~cm}^{2}=4,5 \mathrm{~cm}^{2}$ & $4 \%$ \\
\hline 4 & Coklat & 33,2 kotak x $1 \mathrm{~cm}^{2}=33,2 \mathrm{~cm}^{2}$ & $31 \%$ \\
\hline 5 & Hijau Tua & 50,5 kotak $\times 1 \mathrm{~cm}^{2}=50,5 \mathrm{~cm}^{2}$ & $47 \%$ \\
\hline 6 & Hitam & 3,5 kotak $\times 1 \mathrm{~cm}^{2}=3,5 \mathrm{~cm}^{2}$ & $3 \%$ \\
\hline & Total & 107,7 kotak x $1 \mathrm{~cm}^{2}=107,7 \mathrm{~cm}^{2}$ & $100 \%$ \\
\hline
\end{tabular}

Dari tabel di atas, dapat dilihat warna yang paling dominan atau paling banyak digunakan pada hasil mewarnai ini yaitu warna hijau tua dengan luas sebesar $50,5 \mathrm{~cm}^{2}$. Sehingga dapat disimpulkan subjek yang mewarnai ini dominan menggunakan warna hijau tua yang tergolong warna gelap pada gambar.

Gambar yang yang akan diwarnai, kriteria-kriteria penghitungan luas warna dan norma perhitungan warna dominan akan dipaparkan secara lengkap pada lampiran.

\section{Data Sekunder}

Data sekunder berupa wawancara secara singkat untuk melihat emosi yang dirasakan anak setelah menonton film. Tujuan wawancara untuk mengetahui pemahaman subjek terhadap perlakuan yang diberikan.

Data yang diperoleh berasal dari proses wawancara singkat sesuai panduan yang telah disusun peneliti. Hal ini dipilih mengingat subjek dengan usia 4-6 tahun belum mampu membaca dengan lancar jika diberikan kuesioner. Panduan untuk proses wawancara dipaparkan lengkap pada modul penelitian yang terlampir.

\section{Desain Penelitian dan Prosedur Penelitian}

Penelitian ini menggunakan rancangan atau desain penelitian treatment by subject. Desain ini dipilih karena seluruh subjek mendapat semua perlakuan yang ada tanpa ada yang tertinggal. berikut :

Dengan bentuk rancangan dari penelitian sebagai

$$
\begin{array}{llll}
\mathrm{X}_{1} \mathrm{O}_{1} & \mathrm{X}_{2} \mathrm{O}_{2} & \mathrm{X}_{3} \mathrm{O}_{3} & \mathrm{X}_{4} \mathrm{O}_{4}
\end{array}
$$

$\mathrm{X}_{\mathrm{n}}=$ perlakuan $\mathrm{ke}-\mathrm{n}$ yang didapat

$\mathrm{O}_{\mathrm{n}}=$ pengukuran $\mathrm{ke}-\mathrm{n}$ yang didapat

Rancangan penelitian di atas menjelaskan bahwa ada empat perlakuan dan empat pengukuran yang diberikan pada penelitian ini. Perlakuan berupa penanyangan film dan pengukuran berupa kegiatan mewarnai objek serta wawancara singkat.

Adapun prosedur penelitian yang akan dilakukan adalah sebagai berikut :

1) Semua subjek yang telah didapat dikumpulkan dan dikelompokkan dalam 1 kelompok eksperimen dalam satu ruangan. 
2) Semua subjek dalam kelompok eksperimen akan diinstruksikan untuk menonton film yang ditayangkan. Selama penayangan film kelompok eksperimen diminta memperhatikan film yang berlangsung dan diusahakan tidak melakukan kegiatan lain. Durasi film yang ditampilkan dari 510 menit.

3) Setelah penayangan film, setiap subjek kelompok eksperimen akan diberikan seperangkat alat gambar yang terdiri dari kertas mewarnai berukuran A4 dan krayon 12 warna untuk melakukan kegiatan mewarnai

4) Pengumpulan hasil mewarnai akan dilakukan pada tiap subjek sesuai daftar hadir dari kelompok eksperimen. Dalam pengumpulan gambar, akan dilakukan wawancara singkat.

5) Selang 2 hari kemudian perlakuan akan diberikan kembali pada kelompok eksperimen dengan prosedur yang sama, hanya berbeda pada film yang akan ditampilkan dan juga gambar dari kertas mewarnai yang diberikan.

Pada penelitian eksperimen ini juga dapat dilihat peneliti dalam pengambilan data dibantu oleh asisten peneliti. Penjelasan lebih lengkap mengenai prosedur penelitian dan asisten penelitian dapat dilihat dalam modul eksperimen yang terlampir pada lampiran.

\section{Metode Analisis Data}

Analisis data yang digunakan pada penelitian ini menggunakan teknik statistik non-parametrik dengan uji analisis statistik diawali dengan menghitung nilai Chi-Square. Metode Chi-Square digunakan untuk melihat beberapa faktor dari sampel apakah terdapat hubungan atau perbedaan yang signifikan atau tidak, dimana metode Chi-Square menggunakan data nominal (deskrit) (Alma, 2009).Pada penelitian ini nilai Chi-Square digunakan untuk melihat ada tidaknya hubungan antara variabel bebas yaitu emosi pada variabel tergantung yaitu penggunaan warna dominan.

Uji statistik kedua yaitu Koefisien Kontingensi (Sugiyono, 2011). Koefisien Kontingensi digunakan untuk mengetahui besar derajat hubungan antara variabel yang diuji (Utari, 2009). Pengujian uji nilai Chi-Square dan uji Koefisien Kontingensi akan dibantu dengan program aplikasi komputer SPSS 16.0 for windows, untuk mendapat hasil yang lebih akurat.

\section{HASIL PENELITIAN}

\section{Uji Hipotesis Mayor}

Pengujian hipotesis mayor untuk membuktikan hipotesis null yaitu tidak ada pengaruh emosi terhadap penggunaan warna dominan pada kegiatan mewarnai anak usia dini. Hasil tabulasi data antara total 4 perlakuan dan 4 hasil penggunaan warna dominan yang didapat sebagai berikut
Tabel 2

Tabulasi Data Total 4 Perlakuan*4 Hasil Warna Dominan

\begin{tabular}{|c|c|c|c|c|c|}
\hline & & & \multicolumn{2}{|c|}{$\begin{array}{c}\text { Warna dominan ke- } \\
(1,2,3,4)\end{array}$} & \multirow[t]{2}{*}{ Total } \\
\hline & & & \begin{tabular}{|l|} 
Warna \\
cerah
\end{tabular} & $\begin{array}{l}\text { Warna } \\
\text { gelap }\end{array}$ & \\
\hline \multirow{4}{*}{$\begin{array}{l}\text { Emosi ke- } \\
(1,2,3,4)\end{array}$} & \multirow{2}{*}{\begin{tabular}{|l|} 
Emosi \\
positif \\
\end{tabular}} & Coumt & 52 & 8 & 60 \\
\hline & & $\%$ within emosi $(1,2,3,4)$ & \begin{tabular}{|l|}
$86.7 \%$ \\
\end{tabular} & $13.3 \%$ & $100.0 \%$ \\
\hline & \multirow{2}{*}{$\begin{array}{l}\text { Emosi } \\
\text { negatif }\end{array}$} & Count & 23 & 37 & 60 \\
\hline & & $\%$ within emosi $(1,2,3,4)$ & \begin{tabular}{|l|}
$38.3 \%$ \\
\end{tabular} & $61.7 \%$ & $100.0 \%$ \\
\hline \multirow{2}{*}{\multicolumn{2}{|c|}{ Total }} & \begin{tabular}{|l} 
Count \\
\end{tabular} & 75 & 45 & 120 \\
\hline & & \% within emosi $(1,2,3,4)$ & $62.5 \%$ & $37.5 \%$ & $100.0 \%$ \\
\hline
\end{tabular}

Dari tabel di atas menunjukkan nilai tabulasi total 4 perlakuan emosi dan total 4 hasil warna dominan yang didapat. Secara keseluruhan ketika subjek diberi perlakuan berupa film untuk menstimulasi emosi positif, subjek yang ada memilih menggunakan warna cerah sebanyak 52 subjek atau sebesar $86,7 \%$ dan sebanyak 8 subjek atau sebesar $13,3 \%$ memilih warna gelap dari keseluruhan perlakuan. Selanjutnya ketika subjek diberi perlakuan berupa film dengan emosi negatif, sebanyak 23 subjek atau sebesar 38,3\% menggunakan warna cerah dan sebanyak 37 subjek atau sebesar $61,7 \%$ memilih warna gelap dari keseluruhan perlakuan.

Berikut ini adalah pemaparan mengenai warna-warna cerah dan gelap yang digunakan oleh subjek pada setiap kategori emosi dari seluruh perlakuan :

Tabel 3

Besar Penggunaan Warna Cerah pada Emosi Positif

\begin{tabular}{|c|c|}
\hline Warna Cerah yang Digunakan & Frekuensi \\
\hline Merah muda & 15 subjek \\
\hline Oranye & 9 subjek \\
\hline Kuning & 12 subjek \\
\hline Hijau muda & 2 subjek \\
\hline Biru muda & 6 subjek \\
\hline Ungu & 8 subjek \\
\hline Total & 52 subjek \\
\hline
\end{tabular}

Tabel 4

Besar Penggunaan Warna Gelap pada Emosi Negatif

\begin{tabular}{|c|c|}
\hline Warna Gelap yang Digunakan & Frekuensi \\
\hline Merah tua & 8 subjek \\
\hline Hijau Tua & 3 subjek \\
\hline Biru Tua & 10 subjek \\
\hline Coklat & 8 subjek \\
\hline Abu & 7 subjek \\
\hline Hitam & 1 subjek \\
\hline & Total subjek \\
\hline & Sumber : Data Primer diolah (2013)
\end{tabular}

Selanjutnya untuk mengetahui hubungan yang ada antara emosi dengan warna dominan yang digunakan, dilakukan pengujian untuk mendapatkan nilai Chi-Square. Hasil uji Chi-Square yang didapat sebagai berikut :

Tabel 5

Hasil Uji Chi-Square Total 4 Perlakuan*Total 4 Warna Dominan

\begin{tabular}{|l|l|l|l|l|l|}
\hline & Value & Df & $\begin{array}{l}\text { Asymp.Sig. } \\
\text { (2-sided) }\end{array}$ & $\begin{array}{l}\text { Exact Sig. (2- } \\
\text { sided) }\end{array}$ & $\begin{array}{l}\text { Exact Sig. } \\
(1-\text {-sided })\end{array}$ \\
\hline Pearson Chi-Square & $29.902^{\mathrm{a}}$ & 1 & .000 & & \\
\hline $\begin{array}{l}\text { Contimuity } \\
\text { Correction }\end{array}$ & 27.876 & 1 & .000 & & \\
\hline Likelihood Ratio & 31.774 & 1 & .000 & & \\
\hline Fisher's Exact Test & & & & .000 & .000 \\
\hline $\begin{array}{l}\text { Linear-by-Linear } \\
\text { Association }\end{array}$ & 29.653 & 1 & .000 & & \\
\hline Nof Valid Cases & & & & \\
\hline \\
a. Ocells (.0\%) have expected count less than 5. The minimum expected count is 22.50 \\
b. Computed only for a 2x2 table
\end{tabular}


Dari tabel ini menunjukkan nilai dari Chi-Square sebesar 29,902 dengan nilai df sebesar 1, nilai Chi-Square tabel dengan nilai df 1 dengan signifkansi sebesar 5\% adalah3,841. Sehingga dapat dikatakan bahwa nilai ChiSquare $_{\text {hitung }}>$ Chi-Square $_{\text {tabel }}(29,902$ > 3,841) yang memiliki arti Ho ditolak dan $\mathrm{Ha}$ diterima. Selain itu nilai Asymp.Sig sebesar 0,000 lebih kecil dari $0,05(0,000<0,05)$ juga menegaskan Ho ditolak dan sebaliknya Ha diterima. Sehingga dapat dikatakan bahwa ada pengaruh antara emosi terhadap penggunaan warna dominan pada kegiatan mewarnai anak usia dini.

Kemudian selanjutnya untuk melihat seberapa kuat pengaruh atau hubungan yang ada antara dua variabel ini maka dilakukan pengujian Koefisien Kontingensi, dengan hasil sebagai berikut :

Tabel 6

Symmetric Measures Total 4 Perlakuan*Total 4 Warna Dominan

\begin{tabular}{|c|c|c|c|c|c|}
\hline & & Value & $\begin{array}{l}\text { Asymp. } \\
\text { Sid. Error }\end{array}$ & Approx: $T^{b}$ & $\begin{array}{l}\text { Approx: } \\
\text { Sig. }{ }^{a}\end{array}$ \\
\hline $\begin{array}{ll}\text { Nominal } & b y \\
\text { Nominal }\end{array}$ & $\begin{array}{l}\text { Contingency } \\
\text { Coefficient }\end{array}$ & .447 & & & .000 \\
\hline $\begin{array}{ll}\text { Interval } & \text { by } \\
\text { Interval } & \\
\end{array}$ & Pearson's $R$ & .499 & .076 & 6.258 & $.000^{c}$ \\
\hline $\begin{array}{ll}\text { Ordinal } & \text { by } \\
\text { Ordinal }\end{array}$ & $\begin{array}{l}\text { Spearman } \\
\text { Correlation }\end{array}$ & .499 & .076 & 6.258 & $.000^{c}$ \\
\hline \multicolumn{2}{|l|}{ N of Valid Cases } & 120 & & & \\
\hline
\end{tabular}

b. Using the asymptotic standard error assuming the mull hypothesis.

c. Based on normal approximation.

Sumber : Data Primer diolah (2013)

Dari tabel di atas dapat dilihat nilai Koefisien Kontingensi sebesar 0,447 dan Approx.Sig sebesar 0,000. Nilai Approx Sig. sebesar 0,000 yang berarti lebih kecil dari nilai signifikansi $(0,000<0,05)$ maka Ho ditolak sehingga dapat dikatakan ada pengaruh. Besarnya pengaruh dilihat dari nilai $\mathrm{C}_{\text {hitung }}(0,447)$ yang dibandingkan dengan nilai $\mathrm{C}_{\text {maks }}$ Nilai $\mathrm{C}_{\text {maks }}$ didapat dengan melihat dahulu harga minimum baris dan kolom yang tabelnya telah disajikan pada lampiran. Dari tabel yang ada nilai $\mathrm{C}_{\text {maks }}$ uji ini sebesar 0,707. Dari kriteria nilai $\mathrm{C}$ yang telah dipaparkan sebelumnya, nilai $\mathrm{C}_{\text {hitung }}$ berada pada 0,6 $\mathrm{C}_{\text {maks }}<\mathrm{C}<0,8 \mathrm{C}_{\text {maks }}(0,4242<0,447<0,5656)$ sehingga korelasi yang didapat dalam kategori tinggi atau kuat.

Dari uji yang dilakukan antara total 4 perlakuan dan 4 hasil warna dominan menemukan adanya hubungan atau pengaruh yang kuat atau tinggi antara emosi dengan penggunaan warna dominan pada kegiatan mewarnai anak usia dini.

\section{Uji Hipotesis Minor}

Uji hipotesis minor dilakukan setelah melihat adanya pengaruh antara emosi dan warna pada uji hipotesis mayor. Tujuan dilakukannya uji hipotesis minor ini untuk melihat apakah emosi positif atau emosi negatif yang dirasakan dapat memengaruhi penggunaanwarna dominan yang digunakan oleh subjek penelitian. Hipotesis minor pada penelitian ada dua yang terdiri dari :
1) $\mathrm{Ho}_{1}$ : Tidak ada pengaruh emosi positif terhadap penggunaan warna dominan cerah pada kegiatan mewarnai anak usia dini

$\mathrm{Ha}_{1}$ : Ada pengaruh emosi positif terhadap penggunaan warna dominan cerah pada kegiatan mewarnai anak usia dini

2) $\mathrm{Ho}_{2}$ : Tidak ada pengaruh emosi negatif terhadap penggunaan warna dominan gelap pada kegiatan mewarnai anak usia dini

$\mathrm{Ha}_{2}$ : Ada pengaruh emosi negatif terhadap penggunaan warna dominan gelap pada kegiatan mewarnai anak usia dini

Pengujian dimulai dengan pengujian hipotesis null 1 . Dimulai dari melihat hubungan yang ada antara emosi positif dengan warna dominan cerah yang digunakan, dilakukan pengujian dengan analisis Chi-Square. Hasil nilai uji ChiSquare yang didapat sebagai berikut :

Tabel 7

Uji Chi-Square Emosi Positif* Warna Dominan Cerah

\begin{tabular}{|l|l|l|l|}
\hline & Value & Df & Asymp. Sig. (2-sided) \\
\hline Pearson Chi-Square & $24.330^{\mathrm{a}}$ & 5 & .000 \\
\hline Likelihood Ratio & 16.966 & 5 & .005 \\
\hline Linear-bv-Linear Association & 8.434 & 1 & .004 \\
\hline Nof Valid Cases & 60 & & \\
\hline a. 9 cells (75.0\%) have expected count less than 5. The minimum expected count is.13
\end{tabular}

Antara dua variabel yang diuji. Besarnya pengaruh antara dua variabel dilihat dari nilai $C_{\text {hitung }}(0,537)$ yang dibandingkan dengan nilai $\mathrm{C}_{\text {maks }}$ yang didapat dengan melihat dahuluharga minimum baris dan kolom yang tabelnya telah disajikan pada lampiran. Dari tabel yang ada nilai $\mathrm{C}_{\text {maks }}$ uji ini sebesar 0,707. Dari kriteria nilai $\mathrm{C}$ yang telah dipaparkan sebelumnya, nilai $\mathrm{C}_{\text {hitung }}$ berada pada pada $0,6 \mathrm{C}_{\text {maks }}<\mathrm{C}<0,8$ $\mathrm{C}_{\text {maks }}(0,4242<0,537<0,5656)$ sehingga korelasi yang didapat termasuk dalam kategori tinggi.

Dari uji yang dilakukan antara total emosi positif dengan total warna dominan cerah menemukan adanya hubungan atau pengaruh yang kuat atau tinggi antara emosi positif dengan penggunaan warna dominan cerah pada kegiatan mewarnai anak usia dini.

Pengujian selanjutnya dengan pengujian hipotesis null 2. Dimulai dengan melihat hubungan yang ada antara emosi negatif dengan warna dominan gelap yang digunakan dengan melihat nilai Chi-Square. Hasil uji Chi-Square yang didapat sebagai berikut :

Dari tabel ini menunjukkan nilai dari Chi-Square sebesar 48,729 dengan nilai df sebesar 4, dimana nilai Chi-Square tabel dengan nilai df 4 dengan signifikansi sebesar 5\% adalah 9,488. Sehingga dapat dikatakan bahwa nilai Chi-Square hitung $_{\text {S }}$ $>$ Chi-Square $_{\text {tabel }}(48,729>9,488)$ sehingga Ho ditolak dan Ha diterima. Selain itu nilai Asymp.Sig sebesar 0,000 yang berarti lebih kecil dari $0,05(0,000<0,05)$ juga membuktikan Ho ditolak dan sebaliknya $\mathrm{Ha}$ diterima. Sehingga dapat disimpulkan ada pengaruh antara emosi negatif terhadap 
penggunaan warna dominan gelap pada kegiatan mewarnai anak usia dini.

Untuk melihat seberapa kuat pengaruh atau hubungan yang ada antara dua variabel ini maka dilakukan pengujian Koefisien Kontingensi dengan hasil sebagai berikut :

$$
\text { Tabel } 9
$$

Uji Chi-Square Emosi Negatif*Warna Dominan Gelap

\begin{tabular}{|l|l|l|l|}
\hline & Value & $d f$ & Asymp. Sig. (2-sided) \\
\hline Pearson Chi-Square & $48.729^{\mathrm{a}}$ & 4 & .000 \\
\hline Likelihood Ratio & 62.379 & 4 & .000 \\
\hline Linear-by-Linear Association & 42.936 & 1 & .000 \\
\hline N of Valid Cases & 60 & & \\
\hline a. 9 cells (75.0\%) have expected coumt less than 5. The minimum expected count is .13
\end{tabular}

Sumber : Data Primer diolah (2013)

Dari tabel ini menunjukkan nilai dari Chi-Square sebesar 48,729 dengan nilai df sebesar 4, dimana nilai ChiSquare tabel dengan nilai df 4 dengan signifikansi sebesar 5\% adalah 9,488. Sehingga dapat dikatakan bahwa nilai ChiSquare $_{\text {hitung }}>$ Chi-Square $_{\text {tabel }}(48,729>9,488)$ sehingga Ho ditolak dan Ha diterima. Selain itu nilai Asymp.Sig sebesar 0,000 yang berarti lebih kecil dari $0,05(0,000<0,05)$ juga membuktikan Ho ditolak dan sebaliknya Ha diterima. Sehingga dapat disimpulkan ada pengaruh antara emosi negatif terhadap penggunaan warna dominan gelap pada kegiatan mewarnai anak usia dini.

Untuk melihat seberapa kuat pengaruh atau hubungan yang ada antara dua variabel ini maka dilakukan pengujian Koefisien Kontingensi dengan hasil sebagai berikut : Tabel 10

Symmetric Measures Emosi Negatif*Warna Dominan Gelap

\begin{tabular}{|c|c|c|c|c|c|}
\hline & & Value & $\begin{array}{l}\text { Asymp. } \\
\text { Std. Error }\end{array}$ & Approx. $T^{b}$ & $\begin{array}{l}\text { Approx: } \\
\text { Sig. }{ }^{\circ}\end{array}$ \\
\hline $\begin{array}{ll}\text { Nominal } & \text { by } \\
\text { Nominal } & \\
\end{array}$ & $\begin{array}{l}\text { Contingency } \\
\text { Coefficient }\end{array}$ & .669 & & & .000 \\
\hline $\begin{array}{ll}\text { Interval } & b y \\
\text { Interval } & \end{array}$ & Pearson's $R$ & .853 & .039 & 12.451 & $.000^{\circ}$ \\
\hline $\begin{array}{ll}\text { Ordinal } \\
\text { Ordinal }\end{array} \quad$ by & \begin{tabular}{|l|} 
Spearman \\
Correlation
\end{tabular} & .841 & .040 & 11.861 & $.000^{\circ}$ \\
\hline \multicolumn{2}{|l|}{ Nof Valid Cases } & 60 & 60 & & \\
\hline
\end{tabular}

b. Using the asymptotic standard error assuming the null hypothesis.

c. Based on normal approximation.

Sumber : Data Primer diolah (2013) Dari tabel di atas dapat dilihat nilai Koefisien Kontingensi sebesar 0,669 dan Approx.Sig sebesar 0,000. Nilai Approx Sig. sebesar 0,000 lebih kecil dari nilai signifikansi $(0,000<0,05)$ maka Ho ditolak dapat dikatakan ada pengaruh antara dua variabel yang diuji. Besarnya pengaruh dilihat dari nilai $C_{\text {hitung }}(0,669)$ yang dibandingkan dengan nilai $\mathrm{C}_{\text {maks }}$ yang didapat dengan melihat dahulu dengan melihat harga minimum baris dan kolom yang tabelnya telah disajikan pada lampiran. Dari tabel yang ada nilai $\mathrm{C}_{\text {maks }}$ uji ini sebesar 0,707. Dari kriteria nilai $\mathrm{C}$ yang telah dipaparkan sebelumnya, nilai $\mathrm{C}_{\text {hitung }}$ berada pada pada 0,8 $\mathrm{C}_{\text {maks }}<\mathrm{C}<\mathrm{C}_{\text {maks }}(0,5656<0,669<0,707)$ sehingga korelasi yang didapat dalam kategori sangat tinggi atau sangat kuat.

Kesimpulan yang diperoleh yaitu terdapat pengaruh yang sangat kuat atau sangat tinggi antara emosi negatif dengan penggunaan warna dominan gelap pada kegiatan mewarnai anak usia dini.

\section{PEMBAHASAN DAN KESIMPULAN}

Penelitian ini dilakukan untuk menguji pengaruh emosi yang dirasakan terhadap pilihan warna dominan yang digunakan ketika kegiatan mewarnai oleh anak-anak usia dini. Hasil uji hipotesis mayor memperlihatkan bahwa ada pengaruh emosi terhadap penggunaan warna dominan pada kegiatan mewarnai anak usia dini. Hasil penelitian ini juga didukung oleh pernyataan Goleman (1995) yang menyebutkan bahwa emosi merupakan suatu kondisi yang melibatkan fisiologis, psikologis, dan perasaan untuk bertindak dikarenakan adanya stimulus yang diterima indera dan nantinya akan direspon serta diproses. Salah satu respon ketika emosi telah dirasakan seorang individu, pada hal ini anak-anak adalah dengan menyampaikannya dalam pemilihan warna pada kegiatan seni seperti menggambar dan melukis.

Dari hasil uji Koefisien Kontingensi dihasilkan nilai Koefisien Kontingensi sebesar 0,447 dan Approx.Sig sebesar 0,000 sehingga adanya hubungan atau pengaruh yang tinggi atau kuat dari kedua variabel yang diuji. Kuatnya hubungan yang ada karena film yang digunakan pada perlakuan cukup mampu menstimulasi emosi yang ingin dibangkitkan sehingga warna yang digunakan pun mampu mencerminkan emosi tersebut.

Hasil penelitian ini juga dapat ditegaskan dari penelitian milik Lee, Andrade, \& Palmer (2012) yang menyatakan warna secara spontan dapat dihubungkan dengan keadaan emosi seseorang. Hal ini juga ditegaskan kembali dengan penelitian Jacobs dan Hustmyer (1974) dan Wilson (1966) bahwa emosi memengaruhi warna tidak hanya dilihat dengan pengukuran verbal seperti pengukuran psikologis namun juga pengukuran secara fisiologis yaitu menggunakan GSR dan EEG (dalam Lee, Andrade, \& Palmer, 2012)

Selain hipotesis mayor, peneliti ini juga menguji apakah emosi positif atau emosi negatif yang dirasakan dapat memengaruhi penggunaan warna yang digunakan pada subjek penelitian. Hasil uji analisis untuk hipotesis minor pertama antara emosi positif dengan warna dominan cerah menemukan adanya hubungan antara emosi positif dengan penggunaan warna dominan cerah. Uji kuatnya hubungan atau pengaruh dari hipotesis pertama menemukan hasil nilai Koefisien Kontingensi sebesar 0,537 dan Approx.Sig sebesar 0,000 yang menunjukkan kuatnya pengaruh berada pada kategori tinggi sehingga ada pengaruh yang kuat antara emosi positif dengan warna dominan cerah pada kegiatan mewarnai.

Hal ini juga terjadi pada hipotesis minor kedua antara emosi negatif dengan warna dominan gelap menunjukkan ada hubungan antara 2 variabel yang diuji. Dilanjutkan dengan melihat kuatnya pengaruh melalui nilai Koefisien Kontingensi. Nilai $C_{\text {hitung }}$ yang didapat sebesar 0,669 dan Approx.Sig sebesar 0,000 yang menunjukkan pengaruh dua variabel yang diuji pada kategori sangat tinggi atau sangat kuat. Sehingga dapat disimpulkan bahwa terdapat pengaruh yang sangat kuat 
antara emosi negatif terhadap penggunaan warna dominan gelap pada kegiatan mewarnai.

Hasil uji hipotesis minor ini sejalan dengan beberapa penelitian terdahulu yaitu, pertama penelitian milik Cimbalo, dkk (1978) yang menyebutkan bahwa warna memiliki arti untuk setiap coraknya. Penelitian menemukan hasil ketika anak diberikan stimulus gambar senang mereka mewarnai dengan warna oranye, kuning, hijau, dan biru, sedang ketika diberi gambar sedih mereka mewarnai dengan warna coklat, hitam, dan hijau. Penelitiannya yang lain memaparkan hasil bahwa ketika anak-anak usia pra-sekolahdidengarkan cerita bahagia mereka mewarnai dengan warna kuning dan ketika didengarkan cerita sedih mereka mewarnai dengan warna coklat. Kedua penelitian milik Boyatzis \& Varghese (1994) yang membagi warna atas dua macam yaitu warna yang tergolong cerah (merah muda, merah, kuning, hijau, ungu, dan biru) dan warna yang tergolong gelap (hitam, coklat, dan abuabu) selain itu hasil yang didapat lainnya warna cerah mampu menstimulasi emosi positif dan warna gelap mampu menstimulasi emosi negatif.

Hasil peneliti temukan juga ditegaskan dengan penelitian milik Lee, Andrade, \& Palmer (2012). Penelitian ini menyebutkan ketika individu berada pada satu keadaan emosi tertentu akan memengaruhi individu tersebut dalam memilih satu warna tertentu pula. Hal ini dikarenakan setiap warna memiliki yang disebut dengan nada warna atau color tone. Color tone inilah yang dipersepsi oleh individu memiliki kandungan emosi atau emotional tone yang berbeda-beda untuk setiap warnanya. Disebutkan color tone yang lebih terang (seperti warna kuning dan oranye), lebih bercahaya (warna mendekati warna putih), dan lebih penuh dipersepsikan memiliki emotional tone lebih bahagia, lebih menarik dan murni, sedangkan color tone yang lebih gelap (seperti warna biru dan hitam) dan muted lebih sering asosiasikan dengan emotional tone yang lebih menunjukkan kesedihan, distress, dan jijik. Sehingga dapat disimpulkan mekanisme terjadinya emosi positif atau negatif memengaruhi penggunaan warna dominan cerah atau gelap pada individu khususnya anak usia dini dipaparkan dalam diagram sebagai berikut: usia dini dipaparkan dalam diagram sebagai berikut:



Diagram Hubungan Emosi dan Warna

Ketika individu merasakan suatu emosi baik itu emosi positif atau negatif semuanya memiliki emotional tone tertentu, individu akan lebih memiliki ketertarikansecara positif kepada suatu objek yang dianggap memiliki kesamaan emotional tone dengan yang dirasakannya saat itu.

Salah satu objek yang dimaksud adalah warna. Setiap warna yang ada telah dipersepsi oleh individu ketika melihat warna-warna tersebut. Persepsi ini terjadi dari pengalamanpengalaman diri individu. Persepsi ini memicu individu melihat setiap warna memiliki kandungan emosi yang berbeda-beda atau yang disebut emotional tone yang berbeda. Perbedaan emotional tone pada setiap warna ini disebabkan karena adanya perbedaan nada warna atau color tone.

Adanya kesamaan emotional tone antara warna dengan emosi yang dirasakan individu inilah yang memicu individu memilih hanya beberapa warna dari banyak macam warna yang ada pada kondisi tertentu sehingga memperkuat hasil penelitian bahwa warna dapat memanifestasikan emosi yang dirasakan individu.

Sehingga warna dapat memanifestasikan emosi yang dirasakan individu dan kegiatan mewarnai dapat menjadi metode alternatif untuk mengenali dan memahami emosi anak.

\section{SARAN}

Berdasarkan hasil penelitian yang didapat mengenai pengaruh emosi terhadap penggunaan warna dominan pada kegiatan mewarnai anak usia dini, maka saran yang dapat diberikan antara lain :

1) Saran teoritis :

a. Data-data penelitian serta hasil penelitian yang ditemukan nantinya dapat digunakan sebagai referensi tambahan informasi

b. Hasil penelitian ini dapat dijadikan referensi tambahan untuk ilmu psikologi

2) Saran praktis, kepada pendidik agar memperhatikan hasilhasil seni seperti hasil lukis dan mewarnai pada anak sehingga dapat mengetahui emosi-emosi yang dirasakan anak. Pengetahuan yang tepat tentang emosi yang dirasakan anak didik akan membantu pendidik untuk lebih mengenal anak didik. Fokus sharing antara pendidik dan orangtua bukan hanya mengenai kegiatan akademis namun juga secara sisi sosioemosional anak. Pendidik juga dapat menerapkan kegiatan ini di awal kegiatan sehingga selain lebih mengetahui kesiapan emosional anak didik.

3) Saran bagi peneliti selanjutnya:

a. Peneliti selanjutnya diharapkan mampu menambah jumlah sampel yang digunakan sehingga hasil dapat lebih digeneralisasikan.

b. Rentang waktu antara satu perlakuan ke perlakuan berikutnya lebih lama sehingga anak tidak jemu dan tidak mengalami efek belajar dari perlakuan serupa yang diberikan sebelumnya.

c. Menggunakan objek mewarnai yang berbeda pada setiap perlakuan untuk menghilangkan efek jemu dan efek belajar pada anak. 


\section{DAFTAR PUSTAKA}

Alma, B. (2009). Pengantar Statistika. Bandung: Alfabeta.

Anonim. (2013). Tahap anak mengenal warna. Akses 5 Juni 2013, dari Parenting Indonesia:

http://www.parenting.co.id/article/balita/tahap.anak.mengenal.w arna/001/003/337

AntaraNews. (21 Maret 2012). Jangan remehkan stress pada anak. Akses 7 Nopember 2012, dari Antaranews.com: http://www.antaranews.com/berita/302415/jangan-remehkanstress-pada-anak

Arsynullah, H. (2007). Pengaruh kompleksitas warna dalam perkembangan kreativitas pada anak sekolah. Jurnal Psikoislamika.

Atwater, E. (1983). Psychology of adjusment (second ed.). United State of America.

Azwar, S. (2010). Dasar-dasar psikometri. Yogyakarta: Pustaka Pelajar.

Boyatzis, C. J., \& Varghese, R. Children's emotional associations with colors. The Journal of Genetic Psychology, 155(1), 77-85.

Burger, J. M. (2008). Personality. CA: Wadsworth.

Burkitt, E., Martyn, B., \& Davis, A. (2003). Children's colour choices for completing drawing of affectively characterised topics. Journal of Child Psychology and Psychiatry, 445-455.

Cimbalo, Beck, \& Sendziak. (1972). Emotional toned pictures \& color selection for children and college students. The Journal Genetic of Psychology, 303-304.

DeAngelis, T. (Oktober 2008). Salah satu perawatan untuk gangguan emosional. akses 20 Maret 2012, dari APA: http://www.apa.org/monitor/2008/10/disorders.aspx

Dwisang, E. L. (2002). Kamus lengkap bahasa indonesia. Jakarta: Karisma Publishing Group.

Einon, D. (2006). Permainan kreatif untuk anak-anak. Batam: Karisma Publishing Group.

Ekman, P. (2011). Membaca emosi orang. Jogjakarta: Think Jogjakarta.

Farida. (7 Juli 2009). Manfaat mewarnai bagi si kecil. Akses 13 April 2012, dari Online shop Mommy Gadget: mommygadget.com/2009/07/07/manfaat-mewarnai-bagi-sikecil/

Gayo, I. (26 maret 2013). penghitungan luas are. Akses 5 Juni 2013, dari Keteknikan Hutan:

http://gesangsharewithyou.blogspot.com/2013/03/pengukuranluas-areal.html

Geldard, K., \& Geldard, D. (2012). Konseling anak - anak. Jakarta Barat: PT Indeks.

Hughes, L. (2002). Paving pathways. USA: Wadworth.

Kaya, N., Epps, H. H., \& Hall, D. (n.d.). Relationship between color and emotion : A study of college students. 396- 405.

Kusumastuti, E. D. (27 Desember 2012). Makna di balik coretan tangan. akses 15 Desember 2012, dari Indospiritual.com: http://www.indospiritual.com/artikel_makna-di-balik-coretantangan.html

Lee, C. J., Andrade, E. B., \& Palmer, S. (2012). How emotions influence color preference. Journal of University of California, $1-48$.
Levenson, R. W. (1999). The intrapersonal function of emotion. Cognition and Emotion Psychology Press Ltd , 481-504.

Mashar, R. (2011). Emosi anak usia dini dan strategi pengembangannya. Jakarta: Kencana Prenada Media Group

Matsumoto, D., \& Juang, L. (2008). Culture \& psychology. USA: Thompson \& Wadsworth.

Mendatu, A. (November 2007). Apakah gangguan emosi? Akses 20 Maret 2012, dari Smart psikologi: http://smartpsikologi.blogspot.com/2007/11/apakah-gangguanemosi.html.

Munandar, S. U. (1985). Mengembangkan bakat dan kreativitas anak sekolah. Jakarta: Gramedia.

Munandar, S. U. (1982). Pemanduan anak berbakat. Jakarta: Rajawali.

Munandar, U. (2009). Pengembangan kreativitas anak berbakat. Jakarta: PT Rineka Cipta.

Nando. (2011). Hubungan antara perilaku menonton film kekerasan. Bogor: Departemen sains komunikasi dan pengembangan masyarakat fakultas ekologi manusia institut pertanian bogor.

Napisah, S. (7 April 2013). Laporan praktikum biometrika hutan pengukuran Leaf Area Index (LAI). Akses 15 Juni 2013, dari Blog: http://worldofnaveezha.wordpress.com/2013/04/07/laporanpraktikum-biometrika-hutan-pengukuran-leaf-area-index-lai/

Noviekayanti, I. G. (2010). Pemetaan penyebab stress pada anak. Surabaya: Fakultas Psikologi Universitas 17 Agustus 1945.

Nurani, Y. S. (2011). Konsep dasar pendidikan anak usia dini. Jakarta: PT Indeks.

Nurihsan, A. J., \& Agustin, M. (2011). Dinamika perkembangan anak dan remaja. Bandung: PT Refika Aditama.

Olivia, F. (2011). Merangsang otak anak dengan corat coret. Jakarta : PT Elex Media Komputindo.

Peraturan Menteri Pendidikan Nasional tentang Standar Pendidikan Anak Usia Dini. (2009). Jakarta: Direktorat Pendidikan Anak Usia Dini Direktorat Jenderal Pendidikan Nonformal dan Formal Kementerian Pendidikan Nasional.

Riduwan, \& Sunarto. (2009). Pengantar statistika untuk penelitian. Bandung: Alfabeta.

Santrock, J. W. (2012). Chapter 10 Emotional development. In LifeSpan Development (hal. 346-285). USA: Mc Graw Hill.

Santrock, J. W. (2011). Masa perkembangan anak children. Jakarta: Penerbit Salemba Humanika.

Sugiyono. (2011). Metode penelitian kuantitatif, kualitatif, dan kombinasi (mixed methods). Bandung: Alfabeta.

Sugiyono. (2011). Statistik nonparametris. Bandung: Alfabeta.

Sugiyono. (2008). Statistika untuk penelitian. Bandung: Alfabeta.

Sujiono, Y. N. (2011). Konsep dasar pendidikan anak usia dini. Jakarta: PT Indeks.

Sunyoto, D. (2010). Uji khi kuadrat \& regresi untuk penelitian. Yogyakarta: Graha ilmu.

Suryabrata, S. (2000). Metodelogi penelitian. Jakarta: PT Rajagrafindo Persada.

Susanto, A. (2011). Perkembangan anak usia dini. Jakarta: Kencana Prenada Media Group.

Syaodih, E. (2010). Psikologi perkembangan. 1-27.

Taylor, S. E., Peplau, L. A., \& Sears, D. O. (2009). Psikologi sosial. (T. W. B.S, Trans.) Indonesia. 
Utari, R. (2009). Hubungan tipe kepribadian ekstroversi-introversi dengan coping strategy dalam menghadapi tugas akhir pada wasana praja di institut pemerintahan dalam negeri jatinangorsumedang. UPT Perpustakaan Unisba .

Wahana, K. (2007). Pengolahan data statistik dengan SPSS 15.0. Yogyakarta: Andi Offset.

Walgito, B. (2004). Pengantar psikologi umum. Yogjakarta: Andi Offset.

Wibisono, Y. (2009). Metode statistik. Yogjakarta: Gadjah Mada University Press.

Wikipedia. (10 Mei 2013). Wikipedia:Pedoman ejaan dan penulisan kata. Akses 3 Juni 2013, dari Wikipedia Ensiklopedia Bebas:

http://id.wikipedia.org/wiki/Wikipedia:Pedoman_ejaan_dan_pen ulisan_kata

Wirawan, N. (2001). Cara mudah memahami statistik 1. Denpasar: Keraras Emas 